\title{
Changes in indicators of fibrosis in patients with alcoholic liver cirrhosis associated with non-alcoholic fatty liver disease depending on the stage of cirrhosis
}

\author{
N. R. Matkovska ${ }^{D * 1, A, B, D}$, N. H. Virstiuk ${ }^{1, A, E, F}$, P. R. Herych ${ }^{1, B, C}$, U. V. Balan ${ }^{1,2, B, D}$, \\ Yu. V. Pertsovych ${ }^{2, \mathrm{~B}}$ \\ ${ }^{1}$ Ivano-Frankivsk National Medical University, Ukraine, ${ }^{2}$ Regional Clinical Hospital, Ivano-Frankivsk, Ukraine
}

A - research concept and design; B - collection and/or assembly of data; C - data analysis and interpretation; D - writing the article; $\mathrm{E}$ - critical revision of the article; $\mathrm{F}$ - final approval of the article

Key words: alcoholic liver disease, nonalcoholic fatty liver disease, liver cirrhosis.

Pathologia 2020; 17 (1), 10-14

*E-mail: nmail4you@gmail.com
Objective was to study changes in liver parenchyma fibrosis in patients with alcoholic liver cirrhosis associated with non-alcoholic fatty liver disease depending on decompensation using shear wave elastography and FIB-4 index.

Material and methods. The study included 204 patients. Among them, 78 patients (Group I) had alcoholic liver cirrhosis (ALC) and 126 patients (Group II) had a combination of ALC with non-alcoholic fatty liver disease (NAFLD). Patients were subgrouped according to compensation classes by the Child-Pugh score (A, B, C). The degree of liver parenchyma fibrosis was assessed by calculating the FIB-4 (Fibrolndex-4) and the liver parenchyma elasticity (kPa) determined by the shear wave elastography method.

Results. Values of liver parenchyma elasticity in patients of group II of classes A, B, and C were higher compared to group I same classes $(P<0.05)$. FIB-4 indicators in patients of group II were higher than classes $A, B$, and $C$ compared to group I $(P<0.05)$. In patients with ALC in combination with NAFLD, direct correlations were established between the value of ChildPugh score and the elasticity of the liver parenchyma, the value of the MELD index and the elasticity of the liver parenchyma, the value of Child-Pugh score and FIB-4 index, the value of MELD index and FIB-4 index, FIB-4 index and liver parenchyma elasticity.

Conclusions. In patients with ALC according to elastography and FIB-4 index, fibrosis indicators increase depending on the stage of decompensation. According to elastography and FIB-4 index in patients with ALC, fibrosis indicators were higher in combination with NAFLD at all stages of liver cirrhosis. The magnitude of fibrosis in patients with ALC in combination with NAFLD according to elastography and the FIB-4 index correlates with the severity of liver cirrhosis by Child-Pugh and MELD prognostic index. The combination of shear wave elastography and FIB-4 index are important diagnostic indicators for assessing the degree of fibrosis in the liver.
Киючові слова: алкогольна хвороба печінки, неалкогольна жирова хвороба печінки, цироз печінки.

Патологія. 2020.

T. 17, № 1(48).

C. 10-14

\section{Зміни показників фіброзу у хворих на алкогольний цироз печінки у поєднанні з неалкогольною жировою хворобою печінки залежно від стадії цирозу}

\section{Н. Р. Матковська, Н. Г. Вірстюк, П. Р. Герич, У. В. Балан, Ю. В. Перцович}

Мета роботи - вивчення змін показників фіброзу паренхіми печінки у хворих на алкогольний цироз печінки при поєднанні з неалкогольною жировою хворобою печінки залежно від декомпенсації хвороби, використовуючи зсувнохвильову еластографію та індекс FIB-4.

Матеріали та методи. Обстежили 204 пацієнти: у 78 осіб (I група) діагностували алкогольний цироз печінки (АЦП), у 126 (II група) - поєднання АЦП і неалкогольної жирової хвороби печінки (НАЖХП). Пацієнтів поділили на підгрупи залежно від класів компенсації за критерієм Чайльд-П'ю (А, В, С). Ступінь фіброзу паренхіми печінки оцінювали за допомогою розрахунку індексу фіброзу FIB-4 (Fibrolndex-4) та за величиною еластичності (kPa) паренхіми печінки, яку визначали методом зсувнохвильової еластографії.

Результати. Показник еластичності паренхіми печінки у пацієнтів II групи класів A, B та С був вищим порівняно 3 пацієнтами I групи ( $p<0,05)$. Показники FIB-4 у пацієнтів II групи класів A, B та C були вищі порівняно з такими у I групі $(p<0,05)$. У хворих на АЦП за наявності НАЖХП визначили прямі кореляції між величиною показника Чайлд-П'ю та еластичністю паренхіми печінки, величиною індексу MELD та еластичністю паренхіми печінки, величиною показника Чайлд-П'ю та індексом FIB-4, індексом MELD та індексом FIB-4, індексом FIB-4 та еластичністю паренхіми печінки.

Висновки. У хворих на АЦП, за даними еластографії та за індексом FIB-4, показники фіброзу збільшуються залежно від стадії декомпенсації. За результатами еластографії та за індексом FIB-4, у хворих на АЦП показники фіброзу були більшими за наявності НАЖХП на всіх стадіях цирозу печінки. Величина фіброзу у хворих на АЦП за наявності НАЖХП, за даними еластографії та за індексом FIB-4, корелює з показником тяжкості цирозу печінки Чайлд-П'ю та прогностичним індексом MELD. Поєднання зсувнохвильової еластографії та індексу FIB-4 - важливі діагностичні показники для оцінювання ступеня фіброзоутворення у печінці. 


\section{Изменения показателей фиброза у больных алкогольным циррозом печени при сочетании с неалкогольной жировой болезнью печени в зависимости от стадии цирроза}

\section{Н. Р. Матковская, Н. Г. Вирстюк, П. Р. Герич, У. В. Балан, Ю. В. Перцович}

Цель работы - изучение изменений показателей фиброза паренхимы печени у больных алкогольным циррозом печени при сочетании с неалкогольной жировой болезнью печени в зависимости от декомпенсации болезни с использованием эластографии сдвиговой волны и индекса FIB-4.

Материалы и методы. Обследовали 204 пациента: у 78 человек (I группа) диагностирован алкогольный цирроз печени (АЦП), у 126 (II группа) - сочетание АЦП с неалкогольной жировой болезнью печени (НАЖБП). Пациентов поделили на подгруппы в зависимости от классов компенсации по критерию Чайльд-Пью (А, В, С). Степень фиброза паренхимы печени оценивали с помощью расчета индекса фиброза FIB-4 (Fibrolndex-4) и по величине эластичности (kPa) паренхимы печени, которую определяли методом эластографии сдвиговой волны.

Результаты. Показатель эластичности паренхимы печени у пациентов II группы классов А, В и С был выше по сравнению с пациентами I группы ( $p<0,05)$. Показатели FIB-4 у пациентов II группы классов A, B и C были выше по сравнению с такими показателями I группы $(p<0,05)$. У больных АЦП при наличии НАЖБП установлены прямые корреляции между величиной показателя Чайльд-Пью и эластичностью паренхимы печени, величиной индекса MELD и эластичностью паренхимы печени, величиной показателя Чайльд-Пью и индексом FIB-4, индексом MELD и индексом FIB-4, индексом FIB-4 и эластичностью паренхимы печени.

Выводы. У больных АЦП, по данным эластографии и FIB-4, показатели фиброза увеличиваются в зависимости от стадии декомпенсации. По данным эластографии и FIB-4, у больных АЦП показатели фриброза были выше при наличии НАЖБП на всех стадиях цирроза печени. Величина фиброза у больных АЦП при наличии НАЖБП, по данным эластографрии и FIB-4, коррелирует с показателем тяжести цирроза печени Чайльд-Пью и прогностическим индексом MELD. Сочетание эластографии сдвиговой волны и индекса FIB-4 - важные диагностические показатели для оценки степени фииброзообразования в печени.

According to the World Health Organization, alcohol abuse causes about 3.3 million deaths each year, which is $5.9 \%$ of the total mortality rate. Almost $5 \%$ of overall morbidity and disability are alcohol related. Alcoholic liver cirrhosis (ALC) is the most common disorder of all gastrointestinal tract diseases. In developed countries, alcohol, along with hepatitis $C$ virus and metabolic syndrome are among the leading causes of hepatocellular carcinoma (HCC) [4].

Recently, it has been revealed that non-alcoholic fatty liver disease (NAFLD) is the most prevalent liver disease in Europe, the USA and Asia and is associated with increased mortality. According to Charlton et all, NAFLD is the third most popular indication for liver transplantation in the United States and the only indication that is steadily increasing in frequency $[3,7]$. The prevalence of NAFLD reaches more than $90 \%$ among people suffering from obesity and diabetes $[1,2,9,11]$.

Liver cirrhosis (LC) is considered to be a precursor to the HCC, and its frequency has been constantly increasing [4].

At present, it is important to develop and implement methods for the assessment of fibrosis, and these methods should be convenient-to-use and economically feasible to prevent the progression of prognostically adverse events.

\footnotetext{
Aim

Objective was to study changes in liver parenchyma fibrosis in patients with alcoholic liver cirrhosis associated with non-alcoholic fatty liver disease depending on decompensation using shear wave elastography and FIB-4 index.
}

Ключевые слова: алкогольная болезнь печени, неалкогольная жировая болезнь печени, цирроз печени.

Патология. 2020. T. 17, № 1(48).

C. $10-14$

\section{Material and methods of research}

The study involved 204 patients with diagnosed LC who were hospitalized in the gastroenterology department of the Ivano-Frankivsk Regional Clinical Hospital. Among them, 78 people were diagnosed with ALD at the stage of LC (group I) and 126 people had a combination of alcoholic liver cirrhosis (ALC) with NAFLD (group II). Among the patients of group I there were 24 women and 54 men (mean age $53.2 \pm 11.4$ years) and average duration of the disease $5.9 \pm 2.1$ years; among patients of group II there were 22 women and 104 men aged $47.8 \pm 9.4$ years and average duration of the disease $4.2 \pm 2.7$ years. Patients of groups I and II were subdivided depending on the Child-Pugh classes of $L C$ compensation: IA $(n=17)$, IB $(n=38), I C(n=23) ;\|A(n=44), I I B(n=48)\| C,(n=34)$.

ALC was diagnosed according to the Adapted Clinical Guideline "Alcoholic Liver Disease" (the Ministry of Health of Ukraine, 2014). NAFLD was diagnosed according to the Adapted Clinical Guideline "Non-Alcoholic Fatty Liver Disease" (the Ministry of Health of Ukraine, 2014). The severity of LC was evaluated by Child-Pugh score. MELD index (Mayo Endstage Liver Disease, 2001) was calculated with electronic calculator:

MELD index $=3.8 \times \log _{\mathrm{e}}$ serum bilirubin level $(\mathrm{mg} / \mathrm{dL})$ $+11.2 \times \log _{\mathrm{e}}$ serum creatinine level $(\mathrm{mg} / \mathrm{dL})$.

General clinical, instrumental and laboratory examinations. The degree of liver parenchyma fibrosis was assessed by calculating the FIB-4 (Fibrolndex-4) and the liver parenchyma elasticity $(\mathrm{kPa})$ determined by the shear wave elastography method on the GE Logiq E8 with assessment of the degree of fibrosis on METAVIR scale. The confirmation of the degree of F4 fibrosis by the method of elastography was the value of the elasticity of the liver parenchyma more than $11.9 \mathrm{kPa}$. The 
FIB-4 index was calculated by the formula: (patient age [years] $\times$ ASAT level [U/L]: platelet level $\left[\times 10^{\%} / \mathrm{L}\right] \times$ ALAT $\sqrt{ }$ level [U/L]).

To determine the aetiology of the disease, more than 2 doses of alcohol ( 1 standard dose $=10 \mathrm{~g}$ of ethyl alcohol) per day for women and more than 4 doses for men were considered according to the recommendations of the World Health Organization, CAGE (Cut, Annoyed, Guilty, Eye-opener), AUDIT (Alcohol Use Disorders Identification Test, 1989), PAS questionnaire (post-alcohol syndrome, developed by P. P. Ogurtsov, A. B. Pokrovsky, A. E. Uspensky), LeGo grid (P. M. LeGo (1976) in modification by O. B. Zharkov, 2000), ANI index (Alcoholic liver disease/nonalcoholic fatty liver disease index, 2006), assessment of fat and carbohydrate metabolism (the presence of insulin resistance), NAFLD fibrosis score. The control group consisted of 20 healthy individuals, who were age and gender matched. The study was conducted in accordance with the ethical principles of scientific research, the principles of the Declaration of Helsinki.

Statistical processing of the obtained results was carried out using the software package Statistica v. 12.0 (StatSoft, USA, trial) and Microsoft Excel. The data were checked using the Shapiro-Wilk test. Since the data correspond to the normal type of distribution $(P>0.05)$, the interval $(\mathrm{M} \pm \mathrm{m})$ was chosen as a measure of central tendency. The Student's t-test was used to test the null hypothesis of establishing the difference between the comparison groups; the Newman-Keuls test was used to test the statistical significance of the difference in indicators. For quantitative data, the correlation was estimated using the Pearson parametric method of paired correlation. Statistically significant differences were considered at $P<0.05$. The difference was statistically significant.

\section{Results}

Analyzing the clinical examination data it was found that the signs of astheno-vegetative, pain, dyspeptic, hepatorenal, hepatopulmonary syndromes, jaundice, medicamentally uncontrolled ascites, and manifestations of liver encephalopathy were more frequent in group II patients of the corresponding classes, which was accompanied by a more severe ALC by Child-Pugh severity score and MELD index, that is prognostic index for liver diseases taking into account bilirubin, international normalized ratio (INR) and serum creatinine.

In patients of both groups, they increased with ALC decompensation increasing. However, in patients of group II they were higher than those of group I by $22.74 \%$ and $31.18 \%, 21.06 \%$ and $17.78 \%, 13.72 \%$ and $15.98 \%$ of classes $A, B, C$, respectively $(P<0.05)$. Such results indicate a more severe clinical course and more pronounced rates of progression of hepatic failure in individuals with combination of ALC and NAFLD, which is caused by a more pronounced increase of inflammatory-necrotic process and the process of fibrosis in the liver and is accompanied by pronounced systemic changes in the blood flow, resulting in eventually to the development of multiple organ failure with adverse lethal consequences.

According to the results of the shear wave elastography, the elasticity of the liver parenchyma in all patients corresponded to stage F4 according to the METAVIR classification (Table 1). In both groups, this indicator increased with increasing decompensation of the disease. In particular, in group I elasticity of liver parenchyma in class $B$ exceeded that in class A patients by 1.34 times, and in class $C$ exceeded that in class $B$ persons by 1.24 times $(P<0.05)$. In group II persons, the class $B$ liver parenchyma elasticity index exceeded that in class $A$ by 1.37 times and in class $C$ exceeded that in class $B$ by 1.29 times $(P<0.05)$. Values of liver parenchyma elasticity were higher in group II patients compared to group I patients. In particular, in IIA, IIB and IIC persons, they were higher than the indicators of IA, IB and IC patients by $1.25,1.27$ and 1.32 times, respectively $(P<0.05)$.

The FIB-4 index in patients in both groups increased depending on the stage of decompensation. This indicator was higher in patients of group IB compared to group IA indicator by $14.69 \%$, in the group IC patients compared with group IB - by $7.14 \%$, in group IIB patients compared to group IIA indicator - by $15.36 \%$, in group IIC patients compared to group IIB indicator - by $8.13 \%(P<0.05)$. FIB-4 indicators in patients of group II were higher than classes $A, B$, and $C$ compared to group I by $7.26 \%$, $9.11 \%$, and $10.11 \%$, respectively $(P<0.05)$.

Higher values of liver parenchyma elasticity index and FIB-4 index in group II patients compared with group I patients show more pronounced fibrogenesis processes in patients with combination of ALC and NAFLD. These results indicate the effect of the combination of $A L C$ and NAFLD on the increase in the intensity of fibrogenesis in the liver.

In patients with ALC in combination with NAFLD, direct correlations were established between the value of Child-Pugh score and the elasticity of the liver parenchyma $(r=+0.69$; $P=0.0006)$, the value of the MELD index and the elasticity of the liver parenchyma $(r=+0.61$; $P=0.0003)$, the value of Child-Pugh score and FIB-4 index $(r=+0.67 ; P=0.0005)$, the value of MELD index and FIB-4 index $(r=+0.58$; $P=0.0008)$, FIB-4 index and liver parenchyma elasticity $(r=+0.72 ; P=0.0005)$. Such correlations indicate a direct relationship of fibrosis (according to elastography and FIB-4 index) and Child- Pugh severity score and MELD prognostic index in patients with combination of ALC and NAFLD.

\section{Discussion}

Liver biopsy is considered to be the "gold standard" for the diagnosis of diffuse liver diseases. However, this method is invasive and carries considerable risks and costs [14]. Non-invasive techniques are alternative solution, which will allow evaluating the condition of the liver as a whole but not the particular samples of liver tissue [15].

Non-invasive methods for assessing the degree of liver fibrosis include ultrasound liver elastography and laboratory panels that are widely used in practical medicine. FIB-4 is a laboratory panel comprising four indicators (age, platelet count, alanine aminotransferase and aspartate aminotransferase levels); they are available at primary and secondary medical care and not expensive $[5,6]$. According to many studies, the use of FIB-4 index is recommended for assessment of the degree of liver 
Table 1. Parameters of fibrosis and severity of alcoholic liver cirrhosis depending on the presence of concomitant non-alcoholic fatty liver disease and Childe-Pugh class, $\mathrm{M} \pm \mathrm{m}$

\begin{tabular}{|c|c|c|c|c|c|c|}
\hline \multirow{2}{*}{ Parameters, units } & \multicolumn{2}{|l|}{ Class A } & \multicolumn{2}{|l|}{ Class B } & \multicolumn{2}{|l|}{ Class C } \\
\hline & $\begin{array}{l}\text { Group I, } \\
n=17\end{array}$ & $\begin{array}{l}\text { Group II, } \\
n=44\end{array}$ & $\begin{array}{l}\text { Group } I, \\
n=38\end{array}$ & $\begin{array}{l}\text { Group II, } \\
n=48\end{array}$ & $\begin{array}{l}\text { Group I, } \\
n=23\end{array}$ & $\begin{array}{l}\text { Group II, } \\
n=34\end{array}$ \\
\hline Elasticity of liver parenchyma, $\mathrm{kPa}$ & $15.34 \pm 1.13$ & $19.26 \pm 1.23^{*}$ & $20.63 \pm 1.35^{3}$ & $26.31 \pm 1.27^{1,6}$ & $25.71 \pm 1.13^{4,5}$ & $33.96 \pm 1.22^{2,7,8}$ \\
\hline Index FIB-4 & $3.58 \pm 0.11$ & $3.84 \pm 0.09^{*}$ & $4.06 \pm 0.11^{3}$ & $4.43 \pm 0.08^{1,6}$ & $4.35 \pm 0.07^{4,5}$ & $4.79 \pm 0.06^{2,7.8}$ \\
\hline Child-Pugh score & $5.32 \pm 0.48$ & $6.53 \pm 0.38^{\star}$ & $7.69 \pm 0.52^{3}$ & $9.31 \pm 0.54^{1,6}$ & $12.61 \pm 0.64^{4,5}$ & $14.34 \pm 0.73^{2,7,8}$ \\
\hline Index MELD & $10.23 \pm 0.86$ & $13.42 \pm 0.98^{*}$ & $16.76 \pm 0.83^{3}$ & $19.74 \pm 0.72^{1,6}$ & $23.65 \pm 1.02^{4,5}$ & $27.43 \pm 0.792,7,8$ \\
\hline
\end{tabular}

*: significance of difference of indicators between groups IA i IIA $(P<0.05) ;{ }^{1:}$ : significance of difference of indicators between groups IB i IIB (P < 0.05$) ;{ }^{2}:$ significance of difference of indicators between groups IC i IIC $(P<0.05)$; ${ }^{3}$ : significance of difference of indicators between groups IA i IB $(P<0.05) ;{ }^{4}$ : significance of difference of indicators between groups IB i IC $(P<0.05)$; ; : significance of difference of indicators between groups IA i IC $(P<0.05)$; 6 : significance of difference of indicators between groups IIA i IIB $(P<0.05) ;{ }^{7}$ : significance of difference of indicators between groups IIB i IIC $(P<0.05) ;{ }^{8}$ : significance of difference of indicators between groups IIA i IIC $(P<0.05)$. Indicators of liver parenchyma elasticity according to the results of shear wave elastography and indicators of the FIB-4 index in patients with combination of ALC and NAFLD were higher in classes A, B and C compared to those in patients with ALC without NAFLD. In ALC patients the combination with NAFLD was accompanied by a more severe ALC according to the Child-Pugh score and the MELD prognosis.

fibrosis. Given its noninvasiveness and simplicity, the FIB4 index has the advantage.

However, its use as a single method does not provide sufficient reason to replace the need for a liver biopsy $[10,12,14]$. Ultrasound elastography shows a fairly accurate assessment of the degree of fibrosis and is recommended as an alternative to liver biopsy in patients who cannot undergo invasive procedures $[8,13]$.

In our work, to assess the degree of fibrosis in patients with combination of ALC and NAFLD, we used indicators of liver parenchyma elasticity according to the results of shear wave elastography and FIB-4 index. The fibrosis indicators in patients with combination of ALC and NAFLD were higher in $A, B$, and $C$ classes in comparison with those in ALC patients without NAFLD.

According to our results, in patients with ALC the combination with NAFLD accompanied by a more severe clinical course according to the Child-Pugh score and the MELD index. In patients with combination of ALC and NAFLD we have found a direct correlation of fibrosis (according to elastography indicators and FIB-4 index) with Child-Pugh severity score and MELD index.

As the shear wave elastography and laboratory panel FIB-4, according to the literature [12], show fairly accurate results in the study of liver fibrosis and correlate with the indicators of Child-Pugh and MELD scales, a combination of these methods may, in our opinion, be an alternative to liver biopsy for the assessment of the degree of liver fibrosis and the prediction of the subsequent course of the disease in patients with combination of ALC and NAFLD.

\section{Conclusions}

1. In patients with ALC according to elastography and FIB-4 index, fibrosis indicators increase depending on the stage of decompensation.

2. According to elastography and FIB-4 index in patients with ALC, fibrosis indicators were higher in combination with NAFLD at all stages of liver cirrhosis.

3. The values of fibrosis in patients with ALC in combination with NAFLD according to elastography and the FIB-4 index correlates with the severity of LC by ChildPugh and MELD prognostic index.

4. The combination of shear wave elastography and FIB-4 index are important diagnostic indicators for assessing the degree of fibrosis in the liver in patients with ALC in combination with NAFLD.

The perspective for the further scientific research is to study the treatment of alcoholic liver disease at the stage of cirrhosis associated with non-alcoholic fatty liver disease, depending on the compensation of the disease.

\section{Funding}

The study is carried out according to the plan of scientific works of SHEE "Ivano-Frankivsk National Medical University" and is a fragment of research work: "Diseases of internal organs in modern conditions, with combined pathology and lesions of target organs: features of the course, diagnosis and treatment", number of state registration: $0115 \mathrm{U} 000995$.

Conflicts of interest: authors have no conflict of interest to declare. Конфмікт інтересів: віАсутній.

Надійшла Ао редакції / Received: 16.10.2019

Після Аоопрацювання / Revised: 14.01.2020

Прийнято АО Аруку / Accepted: 15.01.2020

Information about authors:

Matkovska N. R., MD, PhD, Associate Professor

of the Department of Therapy and Family Medicine of

Postgraduate Education Faculty, Ivano-Frankivsk National Medical University, Ukraine.

ORCID ID: 0000-0002-9924-2127

Virstiuk N. H., MD, PhD, DSc, Professor, Head of the Department of Internal Medicine of Stomatological Faculty named after professor M.M. Berezhnytskyi, Ivano-Frankivsk National Medical University, Ukraine.

Herych P. R., MD, PhD, DSc, Professor of the Department of Internal Medicine No. 1, Immunopathology and Allergology named after academician Ye. M. Neiko, Ivano-Frankivsk National Medical University, Ukraine.

Balan U. V., MD, PhD, Assistant of the Department of Internal Medicine No. 1, Immunopathology and Allergology named after academician Ye. M. Neiko, Ivano-Frankivsk National Medical University, Head of Clinical and Diagnostic Laboratory of the Regional Clinical Hospital, Ivano-Frankivsk,

Ukraine.

Pertsovych Yu. V., MD, Doctor of Functional Diagnostics of the Regional Clinical Hospital, Ivano-Frankivsk, Ukraine.

Відомості про авторів:

Матковська Н. Р., канА. меА. наук, Аоцент каф. терапії і сімейної медицини післядипломної освіти, Івано-Франківський національний медичний університет, Україна. 
Вірстюк Н. Г., А-р меА. наук, професор, зав. каф. внутрішньої меАицини стоматологічного факультету імені професора М. М. Бережницького, Івано-Франківський національний меАичний університет, Україна.

Герич П. Р., А-р меА. наук, професор каф. внутрішньої медицини № 1, клінічної імунології та алергології імені академіка $€$. М. Нейка, Івано-Франківський національний медичний університет, Україна.

Балан У. В., канА. меА. наук, асистент каф. внутрішньої медицини № 1, клінічної імунології та алергології імені академіка $€$. М. Нейка, Івано-Франківський національний медичний університет, зав. кмініко-діагностичної лабораторії, Івано-Франківська обласна клінічна лікарня, Україна. Перцович Ю. В., мікар функціональної діагностики, ІваноФранківська обласна киінічна лікарня, Україна.

\section{Сведения об авторах:}

Матковская Н. Р., канА. меА. наук, доцент каф. терапии и семейной медицины послеАипломного образования, ИваноФранковский национальный медицинский университет, Украина.

Вирстюк Н. Г., А-р меА. наук, профессор, зав. каф. внутренней меАицины стоматологического факультета имени профессора М. М. Бережницкого, Ивано-Франковский национальный меАицинский университет, Украина.

Герич П. Р., А-р меА. наук, профессор каф. внутренней медицины № 1, клинической иммунологии и аммергологии имени академика Е. М. Нейко, Ивано-Франковский национальный медицинский университет, Украина. Балан В. В., канА. меА. наук, ассистент каф. внутренней медицины № 1, клинической иммунологии и аммергологии имени академика Е. М. Нейко, Ивано-Франковский национальный медицинский университет, зав. клиникоАиагностической лабораторией, Ивано-Франковская областная клиническая больница, Украина.

Перцович Ю. В., врач функциональной диагностики, Ивано-

Франковская областная клиническая больница, Украина.

\section{References}

[1] Anstee, Q. M., Targher, G., \& Day, C. P. (2013). Progression of NAFLD to diabetes mellitus, cardiovascular disease or cirrhosis. Nature Reviews Gastroenterology \& Hepatology, 10(6), 330-344. https://doi. org/10.1038/nrgastro.2013.41

[2] Wu, S. Q., Wu, F. Q., Ding, Y. Y., Hou, J., Bi, J. F., \& Zhang, Z. (2016). Association of non-alcoholic fatty liver disease with major adverse cardiovascular events: A systematic review and meta-analysis. Scientific Reports, 6. https://doi.org/10.1038/srep33386

[3] Bellentani, S. (2017). The epidemiology of non-alcoholic fatty liver disease. Liver International, 37, 81-84. https://doi.org/10.1111/liv.13299

[4] O'Rourke, J. M., Sagar, V. M., Shah, T., \& Shetty, S. (2018). Carcinogenesis on the background of liver fibrosis: Implications for the management of hepatocellular cancer. World Journal of Gastroenterology, 24(39), 4436-4447. https://doi.org/10.3748/wjg. v24.i39.4436

[5] Castera, L. (2018). Diagnosis of non-alcoholic fatty liver disease/ non-alcoholic steatohepatitis: Non-invasive tests are enough. Liver International, 38, 67-70. https://doi.org/10.1111/liv.13658

[6] Ampuero, J., Pais, R., Aller, R., Gallego-Durán, R., Crespo, J., GarcíaMonzón, C., Boursier, J., Vilar, E., Petta, S., Ming-Hua, Z., Escudero, D., Calleja, J. L., Aspichueta, P., Diago, M., Rosales, J. M., Caballería, J., Gómez-Camarero, J., lacono, O. L., Benlloch, S., Albillos, A., Turnes, J., Banales, J. M., Ratziu, V., \& Romero-Gómez, M. (2019). Development and Validation of Hepamet Fibrosis Scoring System - a Simple, Noninvasive Test to Identify Patients With Nonalcoholic Fatty liver Disease With Advanced Fibrosis. Clinical Gastroenterology and Hepatology, 10, 1-10. https://doi.org/10.1016/j.cgh.2019.05.051

[7] Charlton, M. R., Burns, J. M., Pedersen, R. A., Watt, K. D., Heimbach, J. K., \& Dierkhising, R. A. (2011). Frequency and Outcomes of Liver Transplantation for Nonalcoholic Steatohepatitis in the United States. Gastroenterology, 141(4), 1249-1253. https://doi.org/10.1053/j. gastro.2011.06.061

[8] Hashemi, S. A., Alavian, S. M., \& Gholami-Fesharaki, M. (2016). Assessment of transient elastography (FibroScan) for diagnosis of fibrosis in non-alcoholic fatty liver disease: A systematic review and meta-analysis. Caspian Journal of Internal Medicine, 7(4), 242-252.

[9] Stahl, E. P., Dhindsa, D. S., Lee S. K., Sandesara, P. B., Chalasani, N. P., \& Sperling, L. S. (2019). Nonalcoholic Fatty Liver Disease and the Heart JACC State-of-the-Art Review. Journal of the American college of cardiology, 73(8), 948-963. https://doi.org/10.1016/j. jacc.2018.11.050

[10] Sonneveld, M. J., Brouwer, W. P., Chan, H. L-Y., Piratvisuth, T., Jia, J.-D., Zeuzem, S., Liaw, Y.-F., Hansen, B. E., Choi, H., Wat, C., Pavlovic, V., Gaggar, A., Xie, Q., Buti, M., de Knegt, R. J., \& Janssen, H. L. A. (2019). Optimisation of the use of APRI and FIB-4 to rule out cirrhosis in patients with chronic hepatitis B: results from the SONIC-B study. Lancet Gastroenterol Hepatol, 4(7), 538-544. https://doi.org/10.1016/ S2468-1253(19)30087-1

[11] Potze, W., Siddiqui, M. S., \& Sanyal, A. J. (2015). Vascular Disease in Patients with Nonalcoholic Fatty Liver Disease. Seminars in Thrombosis and Hemostasis, 41(5), 488-493. https://doi. org/10.1055/s-0035-1550433

[12] Papadopoulos, N., Vasileiadi, S., Michalea, S., Antonakaki, P., Papavdi, M., Dellaporta, E., Koullias, E., Koutli, E., Manolakopoulos, S., Koskinas, I. G., \& Deutsch, M. (2019). The use of APRI and FIB-4 scores versus transient elastography for the assessment of liver fibrosis stage in patients with chronic hepatitis $\mathrm{C}$ : Is it possible to reduce the need for elastography? Journal of Hepatology, 70(1), E191-E191. https://doi. org/10.1016/s0618-8278(19)30354-8

[13] Tsai, E., \& Lee, T.-P. (2018). Diagnosis and Evaluation of Nonalcoholic Fatty Liver Disease/Nonalcoholic Steatohepatitis, Including Noninvasive Biomarkers and Transient Elastography. Clinics in Liver Disease, 22(1), 73-92. https://doi.org/10.1016/j.cld.2017.08.004

[14] Cantero, I., Elorz, M., Abete, I., Marin, B. A., Herrero, J. I., Monreal, J. I. Benito, A., Quiroga, J., Martínez, A., Huarte, M. P., \& Isidro, J. (2019) Ultrasound/Elastography techniques, lipidomic and blood markers compared to Magnetic Resonance Imaging in non-alcoholic fatty live disease adults. International Journal of Medical Sciences, 16(1), 75-83. https://doi.org/10.7150/ijms.28044

[15] Vilar-Gomez, E., \& Chalasani, N. (2018). Non-invasive assessment of non-alcoholic fatty liver disease: Clinical prediction rules and bloodbased biomarkers. Journal of Hepatology, 68(2), 305-315. https://doi. org/10.1016/j.jhep.2017.11.013 